\title{
On Citizen Participation in Public Policy
}

\author{
Li Linghua \\ Department of Marxism , \\ Yunnan university of finance and Economics, \\ R. China, \\ 604227454@qq.com
}

\begin{abstract}
Public policies involve the interests of the general public. Therefore, public participations in the formulation, decision-making and implementation of public policies are indispensable. However, there are some problems existing in the process of citizen participation in the formulation of public policies, such as the non-standard participation system, single and narrow ways of citizen participation and the lack of awareness of civic responsibility. This paper starts from the influence of citizen participation and he formulation of public policies, also analyzes he current status of citizen participation in the formulation of current public policies, and finally discusses related innovative policies.
\end{abstract} policy

Keywords-public policy; citizen participation; innovative

Public policy is the programmatic, scheduled, and guiding code of conduct and norms formulated by the state or political party for the goals and tasks of each period. It satisfies the needs of the public and guides the regulation of public behavior. Citizen participation is indispensable, and citizen participation makes public policy formulation more scientific and democratized. Citizens participate in the formulation of public policies through various forms and channels, reflecting the needs of the public from the bottom up which is the manifestations of modern democracy.

\section{ThE NeCESSITY AND IMPORTANCE OF CitiZENS}

\section{PARTICIPATION IN THE Formulation OF PUblic Policy}

\section{A. It helps to improve the democratic nature of public}

\section{policies}

Since the Economic Reform, the country's economy has developed rapidly. The disparity between the rich and the poor has led the social hierarchy. Different classes of people have different demands for social interests. The formulation of public policies must take into account the rational will of the public of different classes. Therefore, the participation of citizens in the formulation of public policies can ensure the democratic nature of the policies and reflect the interests of the public.

\section{B. It helps to improve scientific nature of public policy}

There is no substantive meaning for a single government to formulate public policies. From the top down, the government cannot collect the interest demands of the broad masses of the people. Because of the lack of information, the resulting public policies are distorted and unscientific. The wide participation of citizens can provide useful information for decision making and make the formulation of public policies more scientific.

\section{It is conducive to improve the efficiency of implementing}

\section{public policy}

The participation of citizens in the formulation of public policies guarantees the democratic and scientific nature of public policies, resulting in the approval and acceptance of the made public policies. The implantation from the government faces less resistance and more recognition. Naturally, the efficiency of implementation has also greatly increased.

\section{THE STATUS QUO AND PROBLEMS OF THE CITIZENS'}

\section{PARTICIPATION IN THE FORMULATION OF PUBLIC POLICIES}

\section{IN CHINA}

\section{A. The status of citizens' participation}

Citizen participation is one of the major bodies in the public policy system, but citizens do not think so. Citizens rely on the government's decision-making, and they naturally believe that the government should solve problems when they happened, so they do not take into account their own political participations. This has led most citizens to be indifferent to politics. They hold an attitude of being unrelated or neutral, and their involvement in the formulation of public policies is not positive and active. They consider that it is the affairs of government but not related to themselves. On the other hand, the exposure of government's information is not thorough and careful. Information asymmetry and faults lead to the lack of public confidence in participation. Information disclosure is a governmental initiative, non-compulsory action, so the disclosed information may be comprehensive or incomplete. Therefore, the occlusion of information makes it difficult for the public to obtain favorable public information resources from various sources. This lack of information right leads to the suppression of public participation in policy formulation.

\section{B. Problems in Citizen's Participation in Public Policy}

\section{Formulation}

1) Insufficient quality and ability of citizen participation, lack of representation

China is the second most populous country in the world, with a large population and a wide geographical 
distribution. The popularity of nine-year compulsory education has improved people's education to some extent. However, due to the imbalance of the development in various regions, the overall quality of citizen is not high. The public has a sense of participation, but lacks professional identification skills and communication learning skills in technology. They cannot understand the professional issues in public policy and thus make errors in deviations, leading to difficult implementation of policies.

\section{2) The lack of government's transparency}

Citizen's participation is conducted in an open and transparent manner. Citizens actively participate in the expression of their will through the open information from the government. However, the asymmetric information between the public and the government has led the public to be unaware of the objectives and values of the policy, so the public participation cannot be exerted.

\section{3) 2.2.3 Lack of standardized civic participation system}

Citizens' participation in the formulation of public policies lacks a regular participation system, and there is no clear system to stipulate ways, means, and procedures of participation. The absence of a system makes the public think that participation is only a dispensable political form and does not rise to legal norms, which subsequently makes the public appear randomness and irresponsibility in the process of participation. If the public's willingness and desire are contrary to policy making, there is a lack of standard system to protect civil rights.

\section{4) The manacles of traditional public management}

The mechanism of citizen's participation and the developmental process in our country are not very long. Therefore, many citizens do not have the consciousness to participate in the policy development or public management. Even many public managers do not jump out of the corresponding ideological constraints, resulting in limitation of civic participation mechanisms. Citizens' participation in the formulation of public policies has a low sense of acquisition and enthusiasm. Thus, the desire for citizen participation is high, but there is no corresponding incentive. On the other hand, due to the manacles of traditional thoughts for public management, it has also led to a lack of enthusiasm for innovation and exploration for new management models and a low level of innovation, thus restricting the developmental process of public participation mechanisms.

\section{INNOVATIVE POLICIES TO SOLVE PROBLEMS}

\section{A. Establishing a training system for citizen participation}

China has a large population and a complex population structure. Therefore, citizen's participation needs to be representative. The representatives should be comprised by industry, income, culture and age et al. When the government selects citizens to participate, it should pay attention to the hierarchical representation and formulate a set of training system. Prior training and learning are indispensable. Different groups of people should be explained the value and objectives of the public policy in different ways. Different citizens can better understand this policy and thus propose reasonable and effective interest demands.

\section{B. Strengthening government affairs disclosure and}

\section{government performance evaluation}

Strengthening government affairs disclosure is an effective means to ensure that citizens have the right to know. It is a powerful guarantee for increasing the transparency of the government. It is a symmetry link between the government and the public. The disclosure of government affairs must follow the disclosure of important issues. These important issues concern the basic interests of the public. The public knows the proposal in advance through various channels and can gather useful opinions and suggestions. Open government affairs should also collect public opinions. After disclosure of important issues at each time, the public will be collectively collected for suggestions, and representative public opinions will be collected, and the will of different classes of the public will be integrated to ensure the government's decision-making. Using a third-party assessment team to evaluate government policy development procedures ensures that the policy development meets standards at each step.

\section{Establish and Improve the Legal System of Citizen's}

\section{Participation}

The establishment of a legal system enables citizens to participate in the formulation of public policies with legal guarantees and procedural norms. Citizen's participation should be a normative act, with its own specific scope, procedures, and approaches. These norms need to be strengthened by legislation. When the public's right to participate is infringed and abused, it needs legal assistance and protection. Legislation is strengthened to institutionalize and standardize citizen participation, so that it is better to have laws available, laws must be followed, and violations must be investigated.

\section{Liberate traditional thoughts of public management and}

\section{explore new mechanisms for citizen participation}

Strengthening the study and exchange of successful citizen's participation mechanisms in developed countries and exploring the model suitable for the participation of citizens in public policy formulation in China considering China's national conditions are the two best ways. At the same time, this kind of learning is a learning mode from public administrators to citizens. It is a kind of mature and stable citizen participation mechanism that is led by managers to drive citizens and stimulate citizen's participation through exploration and innovation.

\section{CONCLUSION}

With the development of economy, more and more people demand political participation. This participation is a good interaction between the public and the government, is indispensable for the formulation of public policies, is the best way to realize political rights, and is also the main manifestations of modern democracy. China's current citizen's participation in public policy formulation is still at a stage of exploration and development. Citizen participation mechanism must not only start from the ideological point of view, but also proceed from the legal system and mechanism. Strengthening the transparency of government administration to promote citizens' awareness and enthusiasm for the 
formulation of public policies is important to empower and protect citizens' participation through the establishment of laws and regulations, thereby increasing the sense of citizen participation. Introducing relevant assessment and supervision mechanisms can ensure the orderliness and feasibility of citizen's participation, so that to form a stable and mature public participation mechanism.

\section{REFERENCES}

[1] Guan, L.F., 2009. Analysis of the Institutional Defects and Countermeasures of Citizen Participation in the Formulation of Public Policies in China [J]. Hubei Social Sciences.

[2] Huang, Y.X., 2012.12. Exploring the Path of Citizen Participation in Public Policy from the Perspective of Social Management Innovation [J]. Academician Academic Edition.

[3] Ye, D.F., 2006.3. On citizen participation in the implementation of public policy [J]. Journal of Peking University.
[4] Zhou, X.L., 2005.6. On citizen participation in public policy[J]. Journal of the Party School of the CPC of Changchun City.

[5] Wang, S., Zhao, L., 2008.1. Public organizations involved in the formulation of public policies [J]. Tianfu new theory.

[6] Piao, Z.Z.,2005.2. Policy formulation and citizen participation [J]. Chinese Administration.

[7] Sun, Y.Y., 2006.3. An analysis of the ways of our country citizens to participate in the public policy process [J]. Journal of Guizhou Provincial Party School.

[8] Shi, L., 2007. Study on citizen participation in public decision-making of contemporary Chinese government[D]. Shanghai: East China Normal University.

[9] Liu, X., 2006.5. Institutional Analysis of Failure of Public Policy in Transition Period and Its Preventive Approach [J]. Gansu Journal of Theoretical Studies.

[10] Wang, W.J., 2007. Research on citizen participation in the formulation of public policies in China during transition period[D]. Xi'an: Northwest University. 